\title{
FURTHER RECORDS OF SUMMER FLOCKING OF COMMON LOON
}

\author{
by Robert W. Nero, Department of Mines, Resources and \\ Environment Management, Winnipeg
}

In summer, Common Loons are usually observed singly or in pairs and the occurrence of even a dozen birds in a flock is enough to attract attention. However, flocks of as many as 100 birds have been recorded. The reasons for this unusual behaviour are not all clear.

Rand (1948) briefly examined the nature of summer flocking in the Common Loon as observed by J. M. Harrison for the Flin Flon area of central western Manitoba. Harrison reported daily adult congregations of up to 60 birds on Lake Athapapuskow and more than 100 on File Lake in July 1943, and June and July 1946. Loons flew in to these lakes in the early morning and left in late evening, with flock size reaching a peak about 3:00 p.m. It was suggested by Rand that these were feeding aggregations. It was unclear why loons would leave their young if they were from pairs nesting on nearby smaller lakes, or why they would leave the lake at all if they were non-breeders.

Olson and Marshall (1952: 66-69) presented a discussion of summer flocking based on extensive observations on breeding grounds in Minnesota. Some birds began to associate in flocks early in the season, with the largest flocks forming on the biggest lakes. They considered groups of 10 to 30 or more loons to be major flocks, and noted that such flocks were found on certain areas of the larger lakes year after year. The flocks slowly declined in numbers through September and early October. They believed $t \mathrm{~h}$ at unsuccessful breeding pairs and non-breeding birds were the main components of flocks. Coordinated behaviour within flocks was observed. Feeding formations in particular were notable, birds usually assuming evenly spaced positions in straight lines. Still, the authors con- cluded: "The reasons for flocking are not known."

The present note brings together some additional observations of summer flocking in the Flin Flon area but offers no further explanation of the activity.

Douglas and Dorothy Wade (1963: 138) reported separate flocks of 35 , 57 and 100 loons at Wildnest Lake, about 30 miles northwest of Flin Flon in Saskatchewan, August 18-20, 1963, and stated: "Outside of large but loose concentrations (which could not be called flocks) seen by us off the coast of North Carolina, we had never seen such large, closelyassembled flocks of Common Lwons in salt or fresh water."

James D. Hale and Paul M. Hale reported (pers. commun., 1971) large numbers of loons in late June 1970 on Athapapuskow Lake. They saw an estimated 100-200 birds in scattered small groups over a stretch of nine miles and a concentrated flock of about 50. This was a larger number of loons than they had ever before seen though they had fished for a few days on this same lake during roughly the same period for the past eight years.

Roy A. Reinke, Conservation Officer, has noted (pers. corres., July 30, 1971) large, compact flocks of loons on Kississing Lake, 30 miles north of Flin Flon. "It is safe to say that there would be 100 to 200 in one flock. There seems to be one large flock on the lake with a number of smaller flocks at other points on the lake. The large flock is most always in the same location covering an area of about a square mile in compact groups of 25 to 100 birds. They seem to be in greatest numbers during June and early July." Reinke also reported flocks of up to 100 loons on Second Cranberry Lake. 
These observations, all from within 50 miles of Flin Flon, from 1943 to 1971 , show that summer flocking is of fairly regular occurrence, at least in this area.

Reports of summer flocking of loons on lakes south of Kenora in western Ontario show that the phenomenon is not limited to the Flin Flon region. Robert $R$. Taylor (pers. commun., 1971) observed a flock of 16 at Dogtooth Lake, June 5, 1971, and an estimated 120 strung out in groups of 15 to 20 for three miles on Dryberry Lake, from 5:00 - 6:00 p.m., June 12, 1971. On August 4, 1970, he recorded two flocks of 21 birds each, about one-quarter mile apart on Hillock Lake.

That cooperative group feeding may occur even late in the season is suggested by an observation by Kip Park and Bob DeCruyenaere (pers. commun., October, 1971). An estimated 35 loons were seen fishing in a fairly tight flock occupying a circle of about 200 feet in diameter. When approached by boat, individuals dived when it was about 15 feet away, surfacing almost immediately once it moved out of that range. The boat moved well within the flock, which showed no indication of fear, nor made any attempt to fly off. This was at $3: 30$ p.m. on October 17, 1971, at Shoal Lake, just over the Manitoba border in western Ontario. The lake supports a fairly substantial loon population during the year.

Little information is available on fall migration and it is generally supposed, as reported by Chapman, that "loons move singly or in small groups at considerable height" (in Olson and Marshall, 1952: 69). Palmer (1962: 26-27) notes that "up to 300 birds may gather temporarily on small lakes when migrants encounter adverse weather." Campbell (1970) reported an unusually large number of loons migrating over Mille Lacs Lake in central eastern Minnesota early in the morning of November 11, 1969: "Very conservatively, I would estimate that at least 500 loons passed through my viewing area between $7 \mathrm{a} . \mathrm{m}$. and $9 \mathrm{a} . \mathrm{m}$. of that day. It seems that Mille Lacs is an important link in the migration route of the loons. I suppose this might be because of an abundance of fish like tullibees, central location, and the fact it freezes later than most other lakes."

\section{LITERATURE CITED}

Campbell, T. R. 1970. Loon concentration on Mille Lacs Lake. Loon, $42: 36$.

Olson, S. T., and W. H. Marshall. 1952. The Common Loon in Minnesota. Minn. Museum of Natural History, Occasional Papers No. 5, Univ. Minn. Press. 77 p.

Palmer, R. S. (Ed.) 1962. Handbook of North American birds. Vol. 1, Yale Univ. Press, New Haven. 567 p.

Rand, A. L. 1948. Summer flocking of the loon. Can. field-Nat., $62: 42-43$.

Wade, D. E., and D. R. Wade. 1963. Large concentration of Common Loons on Wildnest Lake. Blue Jay, 21:138.

\section{GREAT CRESTED FLYCATCHER AGAIN OBSERVED IN ALBERTA}

\section{by Graeme M. Greenlee, 10609 - 85 Ave., Edmonton 60}

The evening of June 19, 1971 was clear, calm and warm. My wife and I had driven to a location about nine miles east of Two Hills, Alberta. The site was stop number one of the Breeding Bird Survey which we were going to conduct the following morning. The topography was rolling and the countryside was covered with aspen, broken by scattered small clearing's seeded to tame hay.
The time was about 7:00 p.m. and we were standing beside the car, listening for bird calls. We heard two birds, one on either side of the road, uttering the same call. It was a call neither of us recognized, and could be described as a loud hoarse "cheep." As we began to move toward the source of the nearest call, a bird flew across the road in front of us. We did not immediately recognize it, but 